\title{
IMPROVING MATHEMATICS LEARNING RESULTS BY IMPLEMENTING CIRC COOPERATIVE LEARNING MODEL
}

\author{
KASMIDAWATI
}

\author{
Volume 1 Nomor 2 \\ JIPS \\ ISSN: 2579-5449 \\ E-ISSN: 2597-6540
}

\begin{abstract}
To learn a lesson well, we need to hear, see, ask questions about it, and discuss it with others. Not only that, teachers need to "do it", that is to describe something in their own way, to show their example, to try to practice their skills and to do tasks that demand the knowledge they have gained. The problems to be studied in this research are: Does the implementation of CIRC Cooperative Learningtipe model can improve the learning outcomes of mathematics? Steps taken in this model. Subject peneliatiannya is a fourth grader elementary school, conducted in class IV in addition to researchers teaching this class, because the class has problems according to the studied. Research involving two mathematics teachers in grade IV SDN 07 Pasar Salido. One teacher as the lead researcher and one other teacher as observer. This study was conducted in 3 cycles. Each cycle has 4 stages. Namely (1) Planning, (2) Action, (3) Observation, and (4) Reflection. Data analysis was done by using comparative descriptive analysis that is comparing test value between cycles with work indicator. So the data analysis in this research is

results in the analysis quantitatively based on prosestase. While the data obtained from the observations were analyzed qualitatively. Some conclusions that can be drawn from the results of classroom action research (PTK) is as follows: 1) Student learning motivation in general has increased the average of motivation is quite good at the beginning of $75 \%$ of students to $90 \%$ of students in grade IV SDN 07 Salido Market. This is according to the analysis of the researcher as follows: (1) Students are happy with the variation of the learning model that they think new and they have never been before (2) The learning material discussed is relatively understandable by the students because in the previous school level has been taught. The results of tests performed on each cycle increased, except in cycle III. In cycle I the average value of 65.40 , in cycle II the average value of 69.00 and in cycle III the average value of 68.00 . This is according to the observation and experience of researchers because for the material students in cycle III about the media is relatively more difficult than the material in cycles I and II.
\end{abstract} done both quantitatively and qualitatively. Test

Keywords: mathematics, circ cooperative learning model

MENINGKATKAN HASIL BELAJAR MATEMATIKA DENGAN MENERAPKAN MODEL COOPERATIVE LEARNING TIPE CIRC

\author{
ABSTRAK
}


Untuk bisa mempelajari sesuatu pelajaran dengan baik, kita perlu mendengar, melihat, mengajukan pertanyaan tentangnya, dan membahasnya dengan orang lain. Bukan cuma itu, guru perlu "mengerjakannya", yakni menggambarkan sesuatu dengan cara mereka sendiri, menunjukkan contohnya, mencoba mempraktekkan keterampilan dan mengerjakan tugas yang menuntut pengetahuan yang telah mereka dapatkan.

Permasalahan yang ingin dikaji dalam penelitian ini adalah: Apakah penerapan model Cooperative Learningtipe CIRC dapat meningkatkan hasil belajar matematika ? Langkah - langkah yang dilakukan dalam model ini.

Subjek peneliatiannya adalah siswa kelas IV SD, dilaksanakan di kelas IV disamping peneliti mengajar dikelas ini, karena kelas tersebut mempunyai masalah sesuai yang diteliti. Penelitian yang melibatkan dua orang guru mata pelajaran matematika pada kelas IV SDN 07 Pasar Salido. Satu guru sebagai ketua peneliti dan satu guru yang lain sebagai pengamat.

Penelitian ini dilaksanakan dalam 3 siklus. Setiap siklusnya memiliki 4 tahapan. Yaitu (1) Perencanaan, (2) Tindakan, (3) Pengamatan, dan (4) Refleksi.

Analisa data dilakukan dengan menggunakan analisa deskriptif komperatif yaitu membandingkan nilai test antar siklus dengan indikator kerja. Jadi analisis data pada penelitian ini dilakukan baik secara kuantitatif dan kualitatif. Hasil test di analisis secara kuantitatif berdasarkan prosestase. Sedangkan data yang diperoleh dari hasil observasi dianalisis secara kualitatif.

Beberapa kesimpulan yang dapat ditarik dari hasil penelitian tindakan kelas (PTK) ini adalah sebagai berikut: 1) Motivasi belajar siswa secara umum mengalami kenaikan rata-rata motivasi minimal cukup baik yang awalnya sebesar $75 \%$ siswa menjadi sebesar $90 \%$ siswa di kelas IV SDN 07 Pasar Salido. Hal ini menurut analisis peneliti dikarenakan sebagai berikut: (1) Siswa senang dengan variasi model pembelajaran yang menurut mereka baru dan belum pernah mereka dapat sebelumnya (2) Materi pembelajaran yang dibahas relatif dapat dipahami oleh siswa karena di jenjang sekolah sebelumnya pernah diajarkan. Hasil tes yang dilaksanakan pada setiap siklus mengalami kenaikan, kecuali pada siklus III. Pada siklus I nilai rata-rata sebesar 65,40 , pada siklus II nilai rata-rata sebesar 69,00 dan pada siklus III nilai rata-rata sebesar 68,00. Hal ini menurut pengamatan dan pengalaman peneliti dikarenakan bagi siswa materi pada siklus III mengenai media relatif lebih sulit dari materi pada siklus I dan II.

\section{Kata kunci: matematika, cooperative learning tipe circ}

\section{PENDAHULUAN}

Matematika merupakan salah satu mata pelajaran yang penting diajarkan pada pendidikan dasar dan pendidikan menengah. Dalam pedoman penyusunan Kurikulum Tingkat Satuan Pendidikan Sekolah Menengah Pertama dijelaskan tujuan pengajaran matematika pada pendidikan dasar ( Depdiknas, 2006:8) antara lain agar siswa memahami konsep matematika secara luwes, akurat, efesiarn, dan tepat serta memiliki sikap menghargai kegunaan matematika dalam kehidupan yaitu memiliki rasa ingin tahu atau kritis, perhatian dan minat dalam mempelajari matematika, serta sikap ulet dan percaya sendiri dalam pemecahan masalah.

Berdasarkan pengamatan dan pengalaman penulis dalam mengajar matematika selama ini, siswa kurang memahami materi yang diajarkan guru dan mengalami kesulitan dalam menyelesaikan soal matematika. Pengalaman juga menunjukkan bahwa hasil belajar siswa belum memuaskan.

Hal ini dapat dilihat diantaranya dari nilai ulangan harian pada materi pokok sebelum dilaksanakan penelitian (pra-siklus). Dimana jumlah siswa yang mencapai tingkat ketuntasan belajar baru 37,5 \% dari 40 siswa. Dan rata-rata nilai ulangan hariannya sebesar 43.Gejala-gejala yang tampak pada saat proses belajar antara lain: kemampuan menganalisa dan menyelesaikan soal rendah, siswa kurang terampil berpikir dan cenderung suka mencontoh, siswa belum mampu berfikir kritis dan sistematis. Akibatnya jika diberikan soal-soal yang agak berbeda sedikit 
dengan contoh yang diberikan, mereka tidak mampu menyelesaikannya.

Hal ini disebabkan siswa belajar hanya dengan mengingat fakta, dan kurang memahami konsep yang dipelajari. Selanjutnya melalui sebuah diskusi dengan teman sejawat, penulis mencoba mengidentifikasikan masalah sebagai berikut: (1) pendekatan pembelajaran yang diberikan kurang sesuai (2) metode mengajarnya kurang bervariasi. (3) keterampilan berpikir siswa kurang maksimal. (4) teknik penilaian tidak sesuai sehingga perkembangan kemampuan siswa kurang terukur. (5) pemanfaatan lingkungan/alat peraga kurang, dan dukungan belajar dari orang tua dan masyarakat rendah.

Dengan mencermati juga bahwa di SD Negeri 07 Pasar Salido memiliki kualitas guru yang cukup tinggi ( $99 \%$ sarjana), memiliki alat peraga matematika dan buku-buku yang cukup serta lingkungan sekolah yang mendukung, maka dapat dipahami bahwa rendahnya hasil belajar matematika yang diperoleh siswa disebabkan karena belum diterapkannya model pembelajaran yang dapat membelajarkan siswa secara mandiri, dan dapat membangun kemampuan dan pengetahuan secara bertahap dengan memanfaatkan lingkungan belajar sebagai media pengajaran untuk menyelesaikan soal cerita atau masalah matematika yang berkaitan dengan dunia nyata atau kehidupannya.

Mengingat masalah di atas jika tidak diselesaikan akan berakibat munculnya masalahmasalah yang baru seperti siswa akan semakin kesulitan menerima materi pada kelas berikutnya, peluang tidak lulus setelah ujian dan siswa semakin kurang memaknai dan menyenangi pelajaran matematika, maka sejalan dengan langkah-langkah pemerintah dalam meningkatkan mutu pendidikan baik berupa Dana Bantuan Langsung (DBL) yang disalurkan melalui MGMP Program MERMUTU (Better Education thraogh Reformed Management and Universal Teacher Upgrading) maupun usaha peningkatan kualitas guru melalui pelatihan dan pendidikan bagi guru, penulis berusaha mencari ide atau gagasan tentang bagaimana cara yang tepat untuk meningkatkan hasil belajar matematika yang diperoleh siswa.

Selanjutnya penulis mencoba akan meneliti apakah tindakan kelas dengan menerapkan model Cooperative Learningtipe CIRC (Cooperative Integrated Reading and Composation) dapat meningkatkan hasil belajar matematika pada siswa kelas IV SDN 07 Pasar Salido.

Ada masalah yang nyata, jelas dan mendesak yang di dukung oleh data nyata untuk segera diatasi. Masalah tersebut bermula dari adanya 37,5 \% siswa SD Negeri 07 Pasar Salido. Dalam melaksanakan ulangan harian pada mata pelajaran matematika.

Penyebab masalahnya jelas, yaitu raw input-nya (siswa yang masuk) kurang berkualitas. Dengan demikian, guru mata pelajaran matematika harus berusaha keras agar hasil belajar siswa tentang soal cerita, walaupun kualitas siswanya kurang begitu bagus. Di lain pihak, soal-soal UN banyak yang memuat soalsoal cerita. Padahal sebelum mengerjakan soal cerita, siswa harus bisa memahami makna soal terlebih dahulu. Untuk itu siswa SD Negeri 07 Pasar Salido. Untuk itu perlu dilatih secara dini dalam memahami makna soal cerita untuk kemudian dapat menyelesaikannya.

Sebagai guru matematika yang mengajar di SD Negeri 07 Pasar Salido, maka peneliti merasa tertantang untuk memecahkan persoalan lemahnya siswa dalam menyelesaikan soal cerita. Dalam suatu kesempatan, maka secara kolaborasi, para guru matematika mengidentifikasi masalah yang di hadapi guru dan penyebabnya mengenai lemahnya dalam menyelesaikan soal cerita.

Identifikasi penyebab masalahnya adalah sebagai berikut 1 . Guru belum menemukan model pembelajaran yang tepat untuk melatih siswa dalam menyelesaikan soal cerita. 2. Siswa kelas SD Negeri 07 Pasar Salido dalam menyelesaikan soal cerita metematika mengalami hambatan dalam: a Memahami makna setiap kalimat yang ada dalam soal cerita persegi panjang. $b$ Kurang mampu dalam merumuskan apa yang diketahui dan apa yang ditanyakan, kurang bisa menghubungkan secara fungsional unsur-unsur yang diketahui untuk menyelesaikan masalahnya. c Masih ada yang tidak tahu, unsur mana yang harus dimisalkan dengan suatu variabel.

Oleh karena itu, guru-guru secara kolaboratif mencoba mencari cara dan menemukan model pembelajaran yang tepat agar penyebab masalah yang teridentifikasi di atas dapat segera diatasi.

Hampir semua kompetensi dasar materi matematika di sekolah SD Negeri 07 Pasar Salido ada soal cerita. Soal cerita adalah soal yang dikaitkan dengan kehidupan sehari-hari (contextual problems). Soal cerita dapat dikemas 
dalam bentuk tes objektif maupun dalam benruk soal uraian yang pengerjaannya perlu menuliskan apa yang diketahui, apa yang ditanyakan, dan penyelesaiannya. Kenyataannya, ada beberapa siswa yang mengalami kesulitan dalam memahami arti kalimat-kalimat dalam soal cerita. Oleh karena itu, maka para guru perlu mencari suatu model pembelajaran yang spesifik sehingga keterampilan siswa dalam mengerjakan soal cerita dapat ditingkatkan.

Berdasarkan ide kolaborasi antar guru-guru matematika di SD Negeri 07 Pasar Salido. Maka model Cooperative Learning tipe CIRC (Cooperative Integrated Reading and Composition) berbasis penemuan perlu diimplementasikan guna meningkatkan ketrampilan siswa dalam menyelesaikan soal cerita. Cooperative Learning di dalamnya ada Learning Society yang cocok untuk meningkatkan aktivitas kegiatan belajar.

Dalam Learning Society ini, guru dapat menciptakan suasana sedemikian rupa sehingga siswa aktif untuk saling bertanya, mempertanyakan, dan mengemukakan gagasan dalam kelompoknya. Persoalannya, bagaimankah penerapan model Cooperative Learning CIRC berbasis penemuan dalam mata pelajaran matematika di sekolah untuk meningkatkan kemampuan siswa kelas IV SD dalam menyelesaikan soal-soal aljabar? Untuk kegiatan PTK ini dipilih kelas IV SD disebabkan karena peneliti adalah guru yang mengajar di kelas IV.Atas dasar identifikasi penyebab masalah yang telah diuraikan pada latar belakang di atas, maka masalah yang dihadapi guru SD Negeri 07 Pasar Salido adalah sebagai berikut: Apakah Cooperative Learning Tipe CIRC dapat meningkatkan keterampilan siswa kelas IV SDN 07 Pasar Salido dalam menyelesaikan soalsoal cerita ? Untuk menjawab masalah tersebut di atas, maka secara kolaborasi, bentuk tindakan untuk memecahkan masalahnya adalah dengan diterapkannya model pembelajaran Cooperative

\section{METODE PENELITIAN}

Tempat Penelitian di kelas IV SDN 07 Pasar Salido Kabupaten Pesisir Selatan. Pihak yang terlibat dalam penelitian ini adalah sebagai berikut: a) Subjek peneliatiannya adalah siswa kelas IV SD, dilaksanakan di kelas IV disamping peneliti mengajar dikelas ini, karena kelas tersebut mempunyai masalah sesuai yang diteliti. b) Penelitian yang melibatkan dua orang guru
Learning tipe CIRC (Cooperative Integrated reading and Composition) berbasis penemuan. Implementasi/penerapan model pembelajaran tersebut akan diteliti secra kolaborasi melalui Penilitian Tindakan Kelas. Kolaborasi di lakukan oleh peneliti dengan dibantu guru pelajaran matematika yang lain. Sesuai dengan masalah penelitian yang akan dipecahkan melalui PTK, maka penelitian tindakan berbasis kelas yang akan dilaksanakan ini memiliki tujuan Untuk meningkatkan keterampilan siswa kelas IV SDN 07 Pasar Salido dalam memahami dan menyelesaikan soal persegi panjang melalui model Cooperative Learning Tipe CIRC. (Cooperative Integrated reading and Composition) Berdasarkan kerangka berpikir di atas, maka hipotesis tindakan penelitian ini adalah: dengan menerapkan model pembelajaran tipe CIRC hasil belajar siswa, keterampilan berpikir siswa serta pembelajaran pada materi kesebanguna akan meningkat. Berdasarkan kerangka berpikir di atas, yang mempengaruhi proses belajar antara lain keterampilan berpikir siswa dalam pembelajaran. Maka sebab itu pembelajaran tipe CIRC dalam pelaksanaanya akan memotivasi siswa dalam belajar karena setiap siswa dalam kelompok mempunyai tanggung jawab untuk menguasai materi yang ditugaskan dan dapat mempresentasikan di depan kelas hasil kerja kelompoknya.

Hasil penelitian yang dilaksanakan dengan judul “Penerapan Model Pembelajaran Cooperative tipe CIRC untuk meningkatkan keterampilan siswa dalam menyelesaikan soal pada mata pelajaran matematika".

Menyimpulkan bahwa penerapan model pembelajaran cooperative tipe CIRC dapat meningkatkan keterampilan siswa dalam menyelesaikan soal cerita sehingga berdampak pada peningkatan hasil belajar siswa. Oleh karena itu, peneliti melalui model pembelajaran tipe $C I R C$ ini menduga akan dapat meningkatkan hasil belajar siswa.

mata pelajaran matematika pada kelas IV SDN 07 Pasar Salido. Satu guru sebagai ketua peneliti dan satu guru yang lain sebagai pengamat.

Penelitian ini dilaksanakan dalam 3 siklus. Setiap siklusnya memiliki 4 tahapan. Yaitu (1) Perencanaan, (2) Tindakan, (3) Pengamatan, dan (4) Refleksi.

Seperti pada siklus II, maka kegiatan pada siklus III sama dengan kegiatan pada siklus I dan II. 
Kegiatan pada siklus III merupakan kegiatan perbaikan semua kekurangan pada siklus II. Perbaikan pada siklus III ini didasarkan atas kegiatan refkeksi pada siklus II. Materi pada siklus III melanjutkan materi pada siklus II (berkelanjutan). Di akhir siklus III, kepada para siswa akan dikenai tes tentang materi yang sudah diberikan.

Sumber data diambil dari (1) hasil pengamatan oleh guru pengamat yang dicatat dalam Lembar Observasi dan (2) hasil tes siswa di akhir siklus. Pengambilan data dilakukan pada saat hari masuk sekolah. Cara pengambilan data (1) dibuat Lembar Observasi untuk mengamati proses pembelajaran, aktivitas guru dan siswa serta cara yang efektif dalam menerapkan model pembelajaran Cooperative Learning tipe CIRC berbasis penemuan, (2) dibuat Lembar Kerja Siswa yang berisi soal cerita yang akan dipecahkan siswa melalui cooperative leraning berbasis penemuan, dan (3) sisa diberi tes di akhir siklus III.

Validasi data mencerminkan prestasi belajar siswa dianalisis dari perolehan nilai pra siklus, siklus I, siklus II, siklus III. Perolehan tiap siklus tersebut kemudian dibandingkan untuk menentukan tingkat peningkatan prestasi belajar siswa yang dicapai setelah pelaksanaan model pembelajaran tipe CICR. Sedangkan validitas data untuk mengetahui peningkatan keterampilan dianalis secara kualitatif.

Analisa data dilakukan dengan menggunakan analisa deskriptif komperatif yaitu membandingkan nilai test antar siklus dengan indikator kerja. Jadi analisis data pada penelitian ini dilakukan baik secara kuantitatif dan kualitatif. Hasil test di analisis secara kuantitatif berdasarkan prosestase. Sedangkan data yang diperoleh dari hasil observasi dianalisis secara kualitatif.

Indikator keberhasilan penelitian ini ditandai dengan: 1) Meningkatnya hasil belajar setiap siswa kelas II pada pelajaran matematika khususnya dalam menyelesaikan soal cerita, dengan Kriteria Ketuntasan Minimal 60 (enam puluh) sekitar 85\%. 2) Terjadinya peningkatan keterampilan berpikir siswa, yang ditandai denagn keberanian siswa bertanya, serta tidak ada siswa dalam suatu kelompok yang pasif, sekitar 80\%. 3) Diperoleh cara menerapkan model pembelajaran Tipe CIRC (Cooperative Integrated Reading and composition) berbasis penemuan yang efektif.

\section{HASIL PENELITIAN DAN PEMBAHASAN}

Subyek penelitian tindakan kelas ini adalah siswa dan guru kelas IV. Jumlah siswa kelas IV adalah 40 siswa. Terdiri dari 18 siswa laki-laki dan 22 siswa perempuan yang umumnya memiliki kemampuan sedang. Latar belakang mereka antara lain : (i) berasal dari lingkungan masyarakat yang kesadaran pendidikannya cukup rendah sehingga budaya belajar dilingkungan itu juga rendah, (ii) terlahir dari keluarga yang ekonominya lemah (sebagian besar orang tua mereka adalah petani dan tidak sedikit di antara mereka hanya menggarap sawah milik orang lain), (iii) dukungan belajar dari orang tua sangat rendah, dan (iv) kemampuan menyelesaikan soal cerita cukup rendah. Sekolah tempat peneliti bertugas termasuk Unit Sekolah cukup lama.

Dari instrumen-instrumen yang telah disiapkan untuk menjaring data awal (pratindakan penelitian) melalui dokumentasi siswa dan hasil belajar siswa terhadap mata pelajaran matematika.

Kegiatan pembelajaran pada siklus I dilaksanakan sebanyak 1 kali pertemuan dan setiap pertemuan berlangsung selama 2 jam pelajaran ( 2 x 45 menit). a) Perencanaan dan Persiapan Tindakan

Perencanaan dan persiapan tindakan yang dilakukan peneliti meliputi: 1). Menyusun

Rencana Pelaksanaan Pembelajran (RPP). 2)

Menyiapkan langkah-langkah pada model pembelajaran. 3) Menyiapkan lembar observasi pembelajaran. 4) Menyiapkan LKS. 5)

Menyiapkan kartu soal untuk tournamen. 6) Menyiapkan blangko nilai pada setiap meja kelompok dan blangko nilai kelompok. b Pelaksanaan Tindakan. Kegiatan pelaksanaan pembelajaran pada siklus 1 ini dilaksanakan satu kali pertemuan dengan langkah-langkah yaitu: 1) Guru menjelaskan materi tentang matematika. 2) Siswa membentuk kelompok belajar dan berdiskusi. 3) Permainan 4) Penghargaan kepada kelompok. Pada tahap ini, kegiatan pembelajaran dimulai dengan menjelaskan materi mengenai matematika dengan metode pembelajaran CIRC. Pada akhir penjelasan guru memberikan kesempatan kepada siswa untuk menanyakan kembali materi yang kurang dimengerti sebelum 
kegiatan diskusi kelompok dilaksanakan. Setelah pemberian materi selesai dilaksanakan siswa dikelompokan menjadi 10 (sepuluh) kelompok dengan masing-masing beranggotakan 4 (orang) orang siswa sesuai dengan format pembentukan kelompok belajar siswa yang telah ditentukan pada Pra Kegiatan.

Kemudian guru membagikan LKS materi kemampuan membaca untuk didiskusikan setiap kelompok. Setelah diskusi kelompok selesai maka dilaksanakanlah pertandingan (tournament) dengan langkah-langkah (peraturan) sebagai berikut:

Setiap anggota kelompok memperoleh penomoran 1, 2, 3, 4, yang dipasang di dada masing-masing. Penomoran ini kemudian digunakan untuk menentukan anggota tim tersebut bermain pada meja turnamen ke berapa. Misal pada kelompok Cinderella, salah satu anggota yang bernama Vina diberi nomor 1 oleh guru, ini berarti Vina akan bermain pada meja turnamen 1, Tanti yang diberi nomor 2, berarti akan bermain pada meja turnamen 2 , demikian seterusnya.

Kelompok lain juga demikian, diberi penomoran oleh guru, sehingga semua anggota tim yang memperoleh nomor 1 , akan bermain di meja turnamen 1 , yang memperoleh nomor 2 akan bermain di meja turnamen 2, dan seterusnya.

Setiap meja turnamen terdiri dari 10 orang yang merupakan wakil dari kelompoknya masing-masing. Dalam setiap meja permainan diusahakan agar tidak ada peserta yang berasal dari kelompok yang sama.

Setiap pemain dalam tiap meja menentukan dulu pembaca soal, penulis skor dan pemain yang pertama yang akan menjawab soal dengan cara undian. Kemudian pemain yang menang undian mengambil kartu undian yang berisi nomor soal dan diberikan kepada pembaca soal. Untuk variasi, soal dapat di acak lebih dahulu oleh pembaca soal.

Pembaca soal akan membacakan soal sesuai dengan nomor undian yang diambil oleh pemain. Selanjutnya soal dikerjakan secara mandiri oleh pemain dan penantang sesuai dengan waktu yang telah ditentukan dalam soal.

Setelah waktu untuk mengerjakan soal selesai, maka pemain akan membacakan hasil pekerjaannya yang akan ditanggapi oleh penantang searah jarum jam.

Setelah itu pembaca soal akan membuka kunci jawaban dan skor hanya diberikan kepada pemain yang menjawab benar atau penantang yang pertama kali memberikan jawaban benar.

Jika semua pemain menjawab salah maka kartu dibiarkan saja. Permainan dilanjutkan pada kartu soal berikutnya sampai semua kartu soal habis dibacakan, dimana posisi pemain diputar searah jarum jam agar setiap peserta dalam satu meja turnamen dapat berperan sebagai pembaca soal, penulis nilai, pemain, dan penantang. (Disini permainan dapat dilakukan berkali-kali dengan syarat bahwa setiap peserta harus mempunyai kesempatan yang sama sebagai pemain, penulis nilai, penantang, dan pembaca soal).

Setelah semua kartu selesai terjawab atau karena waktu habis, setiap pemain dalam satu meja menghitung jumlah kartu yang diperoleh dan menentukan berapa skor yang diperoleh berdasarkan tabel yang telah disediakan.

Selanjutnya setiap pemain kembali kepada kelompok asalnya.

Setelah pertandingan berakhir dilakukan penghitungan skor kelompok untuk memberikan penghargaan kelompok. Adapun penghargaan kelompok dengan kriteria seperti tabel berikut ini:

Tabel 2. Kriteria Penghargaan Kelompok
\begin{tabular}{|l|l|}
\hline Nilai Kelompok & Predikat \\
\hline 30 sampai 49 & Tim Cukup \\
\hline 50 sampai 60 & Tim Baik \\
\hline 61 ke atas & Tim Baik Sekali \\
\hline
\end{tabular}

Pelaksanaan pengamatan proses pembelajaran pada siklus ini, siswa sebagian besar antusias mengikuti pembelajaran, hal ini terlihat dari banyaknya siswa yang menanggapi setiap pertanyaan yang diajukan oleh guru mengenai materi yang diajarkan yaitu materi matematika.
Hal lain yang membuat siswa antusias, dari pemberitahuan sebelumnya bahwa nanti dalam pembelajaran ini ada kegiatan permainan. Bahkan sebagian siswa bertanya kepada peneliti permainan yang bagaimana yang membuatnya mereka penasaran. Dalam diskusi kelompok 
terlihat kurangnya kerja sama dari setiap anggota kelompok, meskipun dalam kegiatan pertandingan siswa kelihatan aktif dan antusias dalam menjawab pertanyaan.

Dalam pertandingan tersebut terlihat kurang tertib, hal ini karena banyaknya siswa yang kurang memahami langkah-langkah atau peraturan pertandingan sehingga banyak siswa yang bertanya kepada guru maksud dari langkah yang mereka jalankan. Hasil evaluasi yang diperoleh oleh siswa setelah pelaksanan model pembelajaran media ini menunjukkan hasil ratarata kelas 65,40 , hal ini bisa terlihat dari lampiran.

Dari hasil pengamatan mengenai diskusi kelompok terlihat kurangnya kerja sama dari setiap anggota kelompok, peneliti dan guru observer menyimpulkan bahwa hal ini dikarenakan ada beberapa anggota yang kurang bersemangat dalam belajar, hal ini ditunjukkan dengan hasil angket motivasi belajar sebagai berikut.

Hasil angket motivasi belajar siswa pada siklus I menunjukkan adanya motivasi siswa dengan kriteria sangat baik sebesar 9,20\%, kriteria baik sebesar 30,30\%, kriteria cukup baik sebesar 35,50 \% dan kriteria kurang baik $25 \%$. Hal ini menunjukkan sebanyak $75 \%$ siswa di kelas IV SDN 07 Pasar Salido mempunyai motivasi meskipun motivasi yang paling rendah hanya cukup baik.

Dari hasil pengamatan mengenai kegiatan permainan, terlihat beberapa siswa masih belum paham peraturan-peraturan (langkah-langkah) permainan, oleh sebab itulah pada siklus II guru memberi penjelasan secara terinci mengenai langkah-langkah permainannya, dan guru lebih berperan sebagai motivator baik dalam diskusi kelompok maupun dalam kegiatan permainan.

Dari hasil evaluasi yang menunjukkan hasil ratarata kelas 65,40, ini berarti sudah memenuhi kriteria ketuntasan belajar yang ditetapkan oleh guru mata pelajaran sebesar 63,00.

Kegiatan pembelajaran pada siklus II dilaksanakan sebanyak 1 kali pertemuan dan setiap pertemuan belangsung selama 2 jam pelajaran (2 x 45 menit). Perencanaan dan Persiapan Tindakan Perencanaan dan persiapan tindakan yang dilakukan peneliti meliputi: 1). Menyusun Rencana Pelaksanaan Pembelajaran (RPP) dengan revisi sesuai refleksi siklus I, 2)Menyiapkan langkah-langkah pada model pembelajaran media CIRC 3 Menyiapkan lembar observasi pembelajaran.
Menyiapkan LKS. 5.Menyiapkan kartu soal untuk tournamen. 6) Menyiapkan blangko nilai pada setiap meja kelompok dan blangko nilai kelompok. b Pelaksanaan Tindakan. Kegiatan pelaksanaan pembelajaran pada siklus 1 ini dilaksanakan satu kali pertemuan dengan langkah-langkah yaitu: Guru menjelaskan materi. Siswa membentuk kelompok belajar dan berdiskusi. Permainan. Penghargaan kepada kelompok.

Pada akhir penjelasan guru memberikan kesempatan kepada siswa untuk menanyakan kembali materi yang kurang dimengerti sebelum kegiatan diskusi kelompok dilaksanakan. Setelah pemberian materi selesai dilaksanakan siswa dikelompokan menjadi 10 (sepuluh) kelompok baru yang dibentuk berdasarkan tes formatif setelah siklus I dengan masing-masing beranggotakan 4 (empat) orang. Kemudian guru membagikan LKS materi untuk didiskusikan setiap kelompok.

Setiap anggota kelompok memperoleh penomoran 1, 2, 3, dan 4 yang ditentukan oleh guru. Penomoran ini kemudian digunakan untuk menentukan anggota tim tersebut bermain pada meja turnamen ke berapa.

Kelompok lain juga demikian, diberi penomoran oleh guru, sehingga semua anggota tim yang memperoleh nomor 1 , akan bermain di meja turnamen 1 , yang memperoleh nomor 2 akan bermain di meja turnamen 2, dan seterusnya.

Setiap meja turnamen terdiri dari 10 orang yang merupakan wakil dari kelompoknya masing-masing. Dalam setiap meja permainan diusahakan agar tidak ada peserta yang berasal dari kelompok yang sama.

Setiap pemain dalam tiap meja menentukan dulu pembaca soal dan pemain yang pertama dengan cara undian.

Setelah waktu untuk mengerjakan soal selesai, maka pemain akan membacakan hasil pekerjaannya yang akan ditanggapi oleh penantang searah jarum jam.

Jika semua pemain menjawab salah maka kartu dibiarkan saja. (Disini permainan dapat dilakukan berkali-kali dengan syarat bahwa setiap peserta harus mempunyai kesempatan yang sama sebagai pemain, penantang, dan pembaca soal).

Setelah semua kartu selesai terjawab atau waktu habis, setiap pemain dalam satu meja menghitung jumlah kartu yang diperoleh dan 
menentukan berapa skor yang diperoleh berdasarkan tabel yang telah disediakan.

Selanjutnya setiap pemain kembali kepada kelompok asalnya Pelaksanaan pengamatan proses pembelajaran pada siklus ini, siswa sebagian besar antusias mengikuti pembelajaran, hal ini terlihat dari banyaknya siswa yang menanggapi setiap pertanyaan yang diajukan oleh guru mengenai materi yang diajarkan. Dalam diskusi kelompok yang terlihat lebih aktif kerja sama dari setiap anggota kelompok dibandingkan dengan siklus I. Dalam kegiatan pertandingan siswa kelihatan aktif dan antusias dalam menjawab pertanyaan.

Setiap anggota dari masing-masing kelompok sudah memahami betul peraturan dari permainannya, hal ini dibuktikan lancarnya jalannya permainan tersebut. Pada akhir siklus guru membagikan angket kepada siswa untuk mengungkap motivasi belajar agama islam siswa terhadap tindakan yang diberikan. Hasil evaluasi yang diperoleh oleh siswa setelah pelaksanan model pembelajaran media ini menunjukkan hasil rata-rata kelas 69,00.

Dari hasil pengamatan dalam pelaksanaan model pembelajaran, waktu yang tersedia tidak cukup, hanya sampai pada kegiatan permainan, pada kegiatan pemberian penghargaan tidak sempat dilaksanakan, hal ini karena waktu pembelajaran dipersingkat, sehingga peneliti dan guru pamong menyepakati untuk terpenuhinya waktu dalam pelaksanaan model pembelajaran pada siklus III, maka pelaksanaannya dirancang dua pertemuan, pertemuan pertama kegiatan menjelaskan materi dan diskusi kelompok, sedangkan pertemuan kedua kegiatan permainan (tournament) dan pemberian penghargaan.

Dari hasil evaluasi yang menunjukkan hasil ratarata kelas 69,00, ini berarti sudah memenuhi kriteria ketuntasan belajar yang ditetapkan oleh guru mata pelajaran sebesar 63,00

Kegiatan pembelajaran pada siklus III dilaksanakan sebanyak 1 kali pertemuan selama 2 jam pelajaran ( $2 \times 45$ menit). aPerencanaan dan Persiapan Tindakan Perencanaan dan persiapan tindakan yang dilakukan peneliti meliputi : 1).

Menyusun Rencana Pelaksanaan Pembelajaran (RPP) dengan revisi sesuai refleksi siklus I pada materi matematika. 2).

Menyiapkan langkah-langkah pada model pembelajaran media diskusi 3) Menyiapkan lembar observasi pembelajaran. Menyiapkan LKS. 5) Menyiapkan kartu soal untuk tournamen. 6)Menyiapkan blangko nilai pada setiap meja kelompok dan blangko nilai kelompok.

Kegiatan pelaksanaan pembelajaran pada siklus III ini dilaksanakan satu kali pertemuan dengan langkah-langkah yaitu antara lain : 1) Guru menjelaskan materi tentang matematika. 2) Siswa membentuk kelompok belajar dan berdiskusi. 3) Permainan. 4) Penghargaan kepada kelompok.

Pada tahap ini, kegiatan pembelajaran dimulai dengan menjelaskan materi. Pada akhir penjelasan guru memberikan kesempatan kepada siswa untuk menanyakan kembali materi yang kurang dimengerti sebelum kegiatan diskusi kelompok dilaksanakan

Setelah pemberian materi selesai dilaksanakan siswa dikelompokan menjadi 10 (sepuluh) kelompok seperti pada siklus II. Kemudian guru membagikan LKS materi media diskusi untuk didiskusikan setiap kelompok. Setelah diskusi kelompok selesai maka dilaksanakanlah pertandingan (tournament) dengan langkah-langkah (peraturan) yang sama seperti pada siklus I maupun II. Setelah pertandingan berakhir dilakukan penghitungan skor kelompok untuk memberikan penghargaan kelompok. Adapun penghargaan kelompok dengan kriteria seperti tabel 2.

Pelaksanaan pengamatan proses pembelajaran pada siklus ini, siswa sebagian mengalami kesulitan memahami materi yang diajarkan yaitu matematika, hal ini terlihat dari banyaknya siswa yang bertanya cara mengerjakan soal yang dihadapi dengan gurunya dalam kegiatan dalam diskusi kelompok.

Pada akhir siklus guru membagikan angket kepada siswa untuk mengungkap motivasi belajar matematika siswa terhadap tindakan yang diberikan. Hasil evaluasi yang diperoleh oleh siswa setelah pelaksanan model pembelajaran ini menunjukkan hasil rata-rata kelas 68,00, hal ini bisa terlihat dari lampiran 20 .

Hasil angket motivasi belajar siswa pada siklus III menunjukkan adanya motivasi siswa dengan kriteria sangat baik sebesar 13,10\%, kriteria baik sebesar $35,40 \%$, kriteria cukup baik sebesar 41,50 \% dan kriteria kurang baik $10 \%$. Hal ini menunjukkan sebanyak $90 \%$ siswa di kelas II mempunyai motivasi meskipun motivasi yang paling rendah hanya cukup baik.

Dari hasil evaluasi yang menunjukkan hasil rata4) rata kelas 68,00 , ini berarti sudah memenuhi 
kriteria ketuntasan belajar yang ditetapkan oleh guru mata pelajaran sebesar 63,00

Selama kegiatan berlangsung peneliti mendapatkan beberapa kejadian penting yang dianggap dapat mempengaruhi penelitian antara lain: 1) Penerapan pembelajaran kooperatif melalui media dapat meningkatkat motivasi belajar siswa. Berdasarkan hasil dari penyebaran angket dilihat dari tabel 3 dan tabel 4 yaitu tabel motivasi belajar siswa secara umum dihitung jumlah rata-rata setiap aspek yang diukur mengalami kenaikan dari $75 \%$ menjadi $90 \%$ yang terdiri dari kategori motivasi sangat baik, baik dan cukup baik. 2) Permainan dalam media ini dapat menimbulkan antusias dan semangat

\section{KESIMPULAN DAN SARAN}

Beberapa kesimpulan yang dapat ditarik dari hasil penelitian tindakan kelas (PTK) ini adalah sebagai berikut: (1) Motivasi belajar siswa secara umum mengalami kenaikan ratarata motivasi minimal cukup baik yang awalnya sebesar $75 \%$ siswa menjadi sebesar $90 \%$ siswa di kelas IV SDN 07 Pasar Salido. Hal ini menurut analisis peneliti dikarenakan sebagai berikut: (1) Siswa senang dengan variasi model pembelajaran yang menurut mereka baru dan belum pernah mereka dapat sebelumnya (2) Materi pembelajaran yang dibahas relatif dapat dipahami oleh siswa karena di jenjang sekolah sebelumnya pernah diajarkan. (1) Hasil tes yang dilaksanakan pada setiap siklus mengalami kenaikan, kecuali pada siklus III. Pada siklus I nilai rata-rata sebesar 65,40 , pada siklus II nilai bagi siswa.Pada saat permainan para pemain pada setiap meja turnamen yang merupakan wakil dari kelompok terlihat bersemangat untuk mampu menjawab pertanyaan yang dibacakan, bahkan sebelum pemain yang gilirannya menjawab, ada penantang yang segera ingin menjawab.

Penerapan pembelajaran kooperatif melalui media dapat meningkatkan hasil belajar matematika. Nilai rata-rata siswa setiap siklus mengalami kenaikan. Pada siklus I dengan materi media rata-rata hasil nilai siswa 65,40. Pada siklus II dengan materi media rata-rata hasil nilai siswa 69,00 . Pada siklus III dengan materi media rata-rata hasil nilai siswa 68,00 .

rata-rata sebesar 69,00 dan pada siklus III nilai rata-rata sebesar 68,00. (2) Hal ini menurut pengamatan dan pengalaman peneliti dikarenakan bagi siswa materi pada siklus III mengenai media relatif lebih sulit dari materi pada siklus I dan II.

Beberapa saran yang dapat diberikan dari hasil penelitian tindakan kelas ini adalah sebagai berikut: 1) Penerapan model pembelajaran sebagai salah satu alternatif model pembelajaran bagi guru yang dapat memotivasi belajar matematika. 2) Tournamen/permainan dalam model pembelajaran konstektual, hendaknya dirancang sedemikian rupa sehingga siswa lebih tertarik lagi dan dapat meningkatkan motivasi pada diri siswa yang pada akhirnya dapat meningkatkan prestasi siswa. 


\section{DAFTAR PUSTAKA}

Haryono, Moh.. (2007). Penggunaan Variasi Metode Belajar untuk Membangkitkan Motivasi Belajar Matematika. Widyatama, Vol. 4.

Purwanto, Ngalim. (1996). Psikologi Pendidikan. Bandung. PT. Remaja Rosdakarya.

Sudijono, A. (2005). Pengantar Statistika Pendidikan. PT Raja Grafindo. Jakarta

Suhadi. (2006). Meningkatkan Minat dan Motivasi Belajar Siswa Kelas II SD melalui Model Pembelajaran Kooperatif Tipe TGT (Teams Games Tournaments). http://Suhadinet.wordpress.com. Diakses pada tanggal 15 Agustus 2008.

Suhadi. (2008). Model Pembelajaran Kooperatif tipe CIRC. http://Suhadinet.wordpress.com. Diakses pada tanggal 15 Agustus 2008.
Sumanto, Wasty. (1984). Psikologi Pendidikan (Landasan Kerja Pemimpin Pendidikan. Yogya. Yayasan Paramita.

Sutikno, Sobry. (2007). Menggagas Pembelajaran Efektif dan Bermakna. Bandung. NTP Press.

Trianto, Drs. (2007). Model-model Pembelajaran Inovatif Berorientasi Konstruktivistik. Surabaya. Prestasi Pustaka.

Wardono. (2005). Penerapan Pembelajaran Kooperatif Jigsaw dan TGT (Teams Games Tournaments) untuk Meningkatkan Hasil Belajar Matematika pada Siswa SD. (Laporan PTK). Semarang. 